\title{
Applied Research on Task-based Approach in English Listening Teaching in Higher Vocational Education
}

\author{
Zhang Ting \\ Urban Vocational College of Sichuan
}

Keywords: task-based approach; vocational English listening teaching; application

\begin{abstract}
How to improve the effects of English listening teaching in colleges and universities is an issue which is very much concerned by vocational education at present. As the previous stage of learning English is mainly focusing on theoretical knowledge, with little attention on listening, which leads to many problems for the current vocational colleges to carry out English listening teaching. In today's society, learning English well and communicating in English is a basic skill. In order to help students to lay a good foundation for English communication, it is necessary to improve students' English listening capabilities to a great extent and find out the main problems of English listening teaching in higher vocational colleges. To apply the task-based approach in English listening teaching is of great significance to improve the effects of English listening classes.
\end{abstract}

\section{Introduction}

In the context of great social changes, the deep reform in education, efficient promotion of classroom effects and students' all-round development have become the basic strategies for educating people in the contemporary era. How to improve the English listening ability for vocational students has become an important teaching task. The reasonable application of task-based approach in English listening teaching in higher vocational colleges can help apply the knowledge learned in the classroom to the actual communication process. Emphasize the key points of task in the teaching process, implement the practice into specific tasks so as to help students enhance creative ability and initiative, as well as the overall level of English listening capability.

\section{Applicability Analysis of Task-based Approach in English Listening Teaching}

The task-based approach means the teacher gives a clear task, the student accomplishes the task through concrete operation, and the student's learning ability is improved through the teacher's restraint to the student. Based on this definition, we can see that the core of the task-based approach lies in the tasks, or objectives which seem more appropriate. The objective of the task-based approach is to allow the students grasp more English knowledge through the tasks given by teachers and improve their English listening ability, which is the same goal as higher vocational English listening teaching. Therefore, the task-based teaching approach is very suitable for English listening teaching in higher vocational colleges and it can effectively improve students' learning efficiency and English listening ability.

The process of learning is slow and long-term. For the students in higher vocational colleges, the overall quality of them may not be too high, so the process of teaching is a gentle and upward curve, and the task-based teaching approach is to develop a set task for students at a certain learning period, the upward trend is also a gentle curve, which means easy to be accepted by students. The students in higher vocational colleges have relatively weak learning foundation and incorrect learning attitude, so lots of problems occur in the process of learning. Fast teaching can easily lead to students' failure to correct their problems and snowball phenomenon. Once the teaching method and the learning process conflicts, the learning efficiency of students will be lower. However, the task-based approach and student learning process is consistent, although the early learning efficiency improvement may not be obvious, once the students' foundation is improved and the learning objectives are clarified, their learning efficiency will show a geometric curve growth. 
Although the task-based approach is to give tasks to students by teachers, it does not mean that teachers have always dominated. In the learning process, if the teacher has been the leading role, students will be in a passive position, which leads to dependence on teachers, lack of self-learning ability, and they are not conducive to the cultivation of students' learning ability. The new curriculum reform focuses more on training the students' self-learning ability. In the task-based teaching approach, students and teachers are mutually dominant, which helps to develop students' self-learning ability. The task-based teaching approach is divided into teacher activities and student activities. For the teacher activities, teachers are the main body. Teachers present learning tasks to students, decompose and refine tasks, and guide students to complete their tasks, while in the student activities, students are the main body. Students first need to clear and analyze the learning tasks, and then choose the appropriate method to complete the tasks. Therefore, the task-based approach is suitable for the requirements of the new curriculum reform, and able to improve students' self-learning ability, making teaching tasks more effectively conducted.

\section{Analysis of Problems of English Listening Teaching in Higher Vocational Colleges}

The previous old teaching methods are being adopted in higher vocational colleges for the teaching of listening, and they neither pay attention to the relationship of output link and the input link in the playback process, nor meet the basic laws of language learning of students. Affected by this teaching mode, students and teachers cannot communicate with each other at all. Teachers are basically speaking on the stage while students keep drifting away. In addition, the teachers do not fully understand the students or connect the teaching materials with the actual situation of students, but simply follow the process to conduct teaching. By this teaching mode, it is difficult for students to adapt to the progress of teaching, and some students even give up the subject as they do not understand the class content, which impedes the establishment of students' self-confidence. A cooperative learning platform is not set up for students, instead, it places the teachers in the dominant position, which leads to the decrease of students' interest in learning and thus the effects of listening teaching classes.

In the process of carrying out English listening teaching in higher vocational colleges, common problems are seen such as weak listening ability of students in English and low interest in English listening. English is a second language for students, so it is not easy to learn. As English is not frequently used in life, the students' ability of speaking and listening cannot be effectively improved, therefore, the teachers can make corresponding tasks to require students to practice their listening skills every day. In the long run, students' sense of language and listening ability will be enhanced. Besides, most students in higher vocational colleges also face the problem of incorrect pronunciation, therefore, teachers are supposed to develop students' burst, continuous, and intonation as well as assimilation and other good habits in the daily conversations and English reading process. At present, many students in vocational colleges do not know the intonation and voice changes in language exchange. Due to their poor ability to express in English, they feel difficult to adapt to the speed of listening materials. In addition, many students have a lot of problems in mastery of grammar knowledge and vocabulary, so the ideal audiovisual effects can be hardly achieved during the listening practice.

To achieve the best teaching results of each course, we shall first stimulate students to take the initiative to learn, develop students' sense of independence, so that they could actively cooperate with teachers to achieve an efficient classroom. Students in higher vocational colleges have lower self-learning ability and rely more on teachers. Although the new curriculum reform puts forward new requirements on teachers' teaching methods, the students in higher vocational colleges are deeply influenced by the traditional teaching mode which means teachers have always been speaking and students listening, it is difficult for students to dominate, so the learning pattern shift requires a long-term process. In the process of listening teaching in higher vocational colleges, due to the difficulty of listening teaching materials and the practical limitations of the curriculum, it is far from enough to reply on the practice over class time to help students improve their English listening skills. English teachers in vocational colleges fail to provide students with a relaxed and 
free learning environment, or create a variety of teaching situations, which lead to lower self-learning ability of students.

\section{Applied Analysis on Task-based Approach in English Listening Teaching in Higher Vocational Education}

Make full use of the effective time in the classroom, rely on the lesson plans, and prepare for listening teaching. English teachers in higher vocational colleges can find some suitable language materials before class for students as students in higher vocational colleges have relatively a weak foundation, some difficult listening materials may not fit for them. Some materials with slower speed and clear sentences can be used in class, such as BBC special newscasts. Provide students with these meaningful video materials, triggering students to think about and note down what they hear during playback. If students can accurately hear the statements from the materials, their confidence will also be cultivated. For some more complex materials, group cooperation can be a good form to practice and improve the efficiency.

To accomplish the teaching tasks in class, teachers shall first convey specific tasks to each group so that each group can choose their favorite listening materials, discover the problems during the interactive learning process, and then find an effective solution. Teachers should help students to find difficult words and language-related knowledge in listening comprehension materials during their interactive learning process so as to help students understand the key points of the materials and find out their own existing problems. It is said that the spectators see the chess game better than the players. The teacher's responsibility is to support students to complete teaching tasks and improve their learning ability, which lays a foundation for high-quality teaching tasks to be carried out and helps to trigger students' interest and self-confidence in the listening process.

The preparatory work for teaching tasks must be well conducted for higher vocational colleges to carry out English listening teaching, besides, teachers shall help select suitable listening materials and encourage the groups to express their opinions while listening to the materials. In the final stage of classroom teaching, a fair and reasonable assessment shall be made for each group based on their completion performance of tasks. Teachers can arrange each group members to assess for other groups' performance to ensure the fairness and justice of evaluation. In case of any problem, the teachers must give the correct guidance and avoid conflicts between the groups. Hand over the evaluation right to students, patiently answer the questions in the process of evaluation, and make a summary based on the actual situation of students after the completion of the assessment. Teachers need to not only point out the specific problems that each group encounters in completing their learning tasks, but also praise and encourage students so that students can build up their confidence in English listening comprehension and spark their interest in learning so as to complete the specific tasks in English listening teaching with high quality and performance.

\section{Conclusion}

The most crucial step to develop English teaching in higher vocational colleges is to fully study the learning situation of students and carry out targeted teaching according to specific teaching tasks. Teachers are supposed to provide students with a relaxed and pleasant learning environment, help students find suitable listening materials, and allow the students to play as a leading role, which are of great significance to improve the English listening ability for vocational college students.

\section{References}

[1] Fang Wenli. Research on Foreign Language Task-based Teaching Approach [J]. Foreign Languages and Their Teaching. Volume 09, 2003.

[2] Li Feng. Application and Thinking of Task-based Teaching Approach in English Classes [J]. Journal of Beijing Polytechnic College. Volume 02, 2007. 
[3] Wang Yuehui. Application of Task-based Teaching Approach in Vocational College "English Audio-visual" Course [J]. Journal of Beijing Institute of Economic Management. Volume 03, 2011. 